Забелина Маргарита Васильевна, д-р биол. наук, проф. кафедры «Технология производства и переработки продукции животноводства», Саратовский государственный аграрный үниверситет имени Н.И. Вавилова. Россия. ключевые слова: минеральная подкормка; аспарагинат кобальта; пчеловодство; обмен веществ; ферменты; питательные вещества.

\title{
THE INFLUENCE OF COBALT ASPARAGINAT ON METABOLIC RATES OF CARPATHIAN BEES
}

Orlova Elena Nikolaevna, Post-graduate Student of the chair "Diseases of Animals and Veterinarian and Sanitarian Expertise", Saratov State Agrarian University named after N.I. Vavilov. Russia.

Rodionova Tamara Nikolaevna, Doctor of Biological Sciences, Professor of the chair "Diseases of Animals and Veterinarian and Sanitarian Expertise", Saratov State Agrarian University named after N.I. Vavilov. Russia.

Strogov Vladimir Viktorovich, Candidate of Biological Sciences, Associate Pro-fessor of the chair "Diseases of Animals and Veterinarian and Sanitarian Exper-tise”, Saratov State Agrarian University named after N.I. Vavilov. Russia.

Zabelina Margarita Vasylyevna, Doctor of Biological Sciences, Professor of the chair "Technology of Production and Processing of Livestock Products", Saratov State Agrarian University named after

\section{N.I. Vavilov. Russia.}

Keywords: cobalt asparaginate; beekeeping; metabolism; enzymes; nutrients.

The effect of cobalt aspartate on the activity of some enzymes involved in the metabolism of bees of the Carpathian rock was studied. Studies were conducted on the nomad apiary of the Saratov region of the Saratov region near the village of Pe-schaniy Umet. The results of the research showed that the bees in the experimental group who receiving mineral supplementation with the cobalt asparaginate preparation at a dose of $4 \mathrm{mg} / \mathrm{l}$ (in terms of the active substance) promotes an increase in the activity of enzymes such as catalase rectal glands, peroxidase, invertase of hypopharyngial glands, total nitrogen, crude fat and glycogen, compared to the control group.

удк 635.342: 631.62: 661.162.6 [470.4]

\section{ВЛИЯНИЕ ПРЕПАРАТОВ НА ОСНОВЕ ГУМИНОВЫХ КИСЛОТ НА ПРОДУКТИВНОСТЬ КАПУСТЫ БЕЛОКОЧАННОЙ В САРАТОВСКОМ ЗАВОЛЖЬЕ ПРИ ОРОШЕНИИ}

\author{
ПРОНЬКО Нина Анатольевна, Саратовский государственный аграрный университет
} имени Н.И. Вавилова

ШУШКОВ Юрий Сергеевич, Саратовский государственный аграрный университет имени Н.И. Вавилова

\section{ПРОНЬКО Виктор Васильевич, НПО «Сила жизни»}

Изучено влияние препаратов на основе гуминовых кислот на продуктивность капусты белокочанной поздней гибрида Агрессор. Установлено, ито опрыскивание растений раствором Реасила микро гидро микс повысило урожайность на 15,8 m/га (21\% выше контроля), а обработка Гуматом калия-натрия с микроэлементами - на 10,25 m/2а (14\% к контролю). Максимальная урожайность капусты белокочанной $(100,81 \mathrm{~m} / 2 a)$ получена после двукратного применения Реасила форте амино магния на фоне Реасила микро гидро микс. Все изучаемые препараты положительно влияли на такие показатели качества урожая, как накопление сухого вещества, витамина С, сумма сахаров и содержание элементов питания. Они также способствовали увеличению выноса с урожаем из почвы азота, фосфора и калия. На содержание нитратного азота в продукци препараты не повлияли.

Введение. Среди овощных культур, возделываемых в Саратовской области, капусте белокочанной отводятся довольно большие посевные площади. За 2013-2017 гг. они составляли от 2296 до 2675 га (12,713,1 \% от общей посевной площади овощных культур). Однако продуктивность капусты белокочанной за эти годы оставалась достаточно низкой: в среднем по области она колебалась от 30,6 до 33,3 т/га.

В последние годы сельхозтоваропроизводители для повышения урожайности стали широко применять различные биологические препараты, регуляторы роста растений и микроэлементные удобрения [6]. Ассортимент перечисленной продукции достаточно широкий [5], а их действие на многих сельскохозяйственных культурах до сих пор не изучалось. Для орошаемых условий Саратовского Заволжья имеются сведения о высокой эффективности препаратов на основе гуминовых кислот при возделывании огурца [3] и томата [4]. На капусте белокочанной ранее подобные препараты не испытывались.

Цель нашей работы - изучить отзывчивость растений капусты белокочанной поздней гибрида Агрессор на препараты на основе гуминовых кислот производства НПО «Сила жизни» в Саратовском Заволжье при орошении.

Методика исследований. Объектами исследований были капуста белокочанная поздняя гибрида Агрессор и препараты на основе гуминовых кислот, производимые НПО «Сила жизни» (г. Саратов). Приводим их химический состав (в весовых процентах). Гумат калия-натрия с микроэлементами: гуминовые кислоты (гуматы) - 7,00; гидроксикарбоновые кислоты (глюконовая, молочная, янтарная, лимонная и др.) - 0,60; аминокислоты (L-глицин, L-лизин, L-треонин и др.) - 2,40; азот - 3,50; фосфор - 0,50; калий - 2,50; магний 0,10 ; бор (бороэтаноламин) - 0,10; кобальт - 0,01; медь - 0,05; железо - 0,12; марганец - 0,10; молибден - 0,03; цинк - 0,12. Реасил микро гидро микс: гидроксикарбоновые кислоты - 18,00; аминокислоты - 8,00; азот - 12,00; магний - 4,00; бор (бороэтаноламин) - 2,00; кобальт - 0,10; медь - 0,80; 
железо - 5,00; марганец - 2,50; молибден - 0,25; цинк - 3,00. Реасил форте карб-кальций-амино: гидроксикарбоновые кислоты - 16,00; аминокислоты - 4,00; азот - 18,00; кальций - 16,00. Реасил форте амино медь: гидроксикарбоновые кислоты - 20,00; аминокислоты - 8,00; азот - 10,00; медь - 10,00. Реасил форте амино марганец: гидроксикарбоновые кислоты - 18,00; аминокислоты - 8,00; азот - 10,00; марганец - 10,00. Реасил форте амино магний: гидроксикарбоновые кислоты - 14,00; аминокислоты - 4,00; азот - 18,00; магний - 14,00.

Полевые опыты по изучению эффективности перечисленных выше препаратов проводили в 2013-2015 гг. в К(Ф)X «Семья Жайлауловых» (Энгельсский р-н Саратовской обл.) в условиях орошения. Почва опытного участка, расположенного на третьей надпойменной террасе левого берега Волги, - темно-каштановая среднегумусная среднесуглинистая несолонцеватая. Обеспеченность (для овощных культур) доступными формами азота средняя (40-50 мг/кг легко гидролизуемого азота по Тюрину -Кононовой), фосфором - низкая (31-45 мг/кг по Мачигину), обменным калием - повышенная (201300 мг/кг в углеаммонийной вытяжке).

Размер учетной делянки - 22,4 $\mathrm{m}^{2}$, повторность вариантов - четырехкратная, расположение делянок - систематическое двухрядное. Закладывали опыты следующим образом. На 8-10-й день после высадки рассады растения обрабатывали водными растворами Реасила микро гидро микс (Фон 1) и Гумата калия-натрия с микроэлементами (Фон 2). Затем на этих фонах дважды осуществляли опрыскивания препаратами, содержащими мезо- и макроэлементы в периоды начала завязывания кочанов и их активного роста, с интервалами 20-25 дней. Норма расхода всех препаратов - 1,0 л/га на каждую обработку. Капусту поливали установкой для мелкодисперсного дождевания Райн стар E-241. Опрыскивания растений и уборку урожая проводили вручную.

Постановку полевых опытов и статистическую обработку данных осуществляли по методике Б.А. Доспехова [1]. Химический анализ урожая производили по общепринятым методикам [2]. Содержание азота, фосфора, калия определяли после мокрого озоления по Гинзбург, нитратного азота - ионометрически в растворе алюмокалиевых квасцов, витамина С (аскорбиновой кислоты) - по Мурри после экстрагирования смесью соляной и метафосфорной кислот, сумму сахаров - по Бертрану.

Результаты исследований. За время проведения полевых опытов погодные условия вегетационного периода отличались по гидротермическим показателям. Наименее благоприятным для роста и развития капусты позднеспелой оказался 2014 г., что негативно сказалось на ее урожайности. В 2013 г. на контрольном варианте было собрано 85,40 т/га капусты, а в 2014 г. на $19 \%$ меньше (табл. 1 ).

Обработка растений раствором Реасила микро гидро микс (вариант 2) позволила существенно (на $21 \%$ выше контроля) повысить урожайность данной культуры. Наиболее эффективно действие этого препарата проявилось в 2015 г.

Применение на фоне Реасила микро гидро микс изучаемых микроэлементных препаратов (варианты 3-6) оказало неоднозначное действие. В 2013 г. достоверные прибавки урожая к фону (вариант 2) были отмечены только при обработках растворами с повышенным содержанием марганца (вариант 5) и магния (вариант 6). В 2014 г. статистически значимые приросты урожая к Фону 1 показали все изучаемые препараты (варианты 3-6). Та же картина имела место и в 2015 г. В среднем за три года исследований на фоне Реасила микро гидро микс самая высокая прибавка урожая сложилась при обработках капусты белокочанной раствором Реасила форте амино магний (вариант 6). Это сочетание обеспечило также и максимальную в условиях наших экспериментов продуктивность данной культуры.

Гумат калия-натрия с микроэлементами (вариант 7) по своей эффективности заметно уступил Реасилу микро гидро микс (вариант 2). Причина этого в том, что концентрация макро- и микроэлементов в Реасиле выше, чем в Гумате. Следует также отметить, что использование препаратов с повышенным содержание кальция, меди и марганца (варианты 8-10) не обеспечило достоверного повышения урожайности капусты белокочанной по отношению к варианту 7 (Фон 2).

Таким образом, в среднем за три года самая высокая продуктивность капусты белокочанной поздней гибрида Агрессор была получена при сочетании Реасила микро гидро микс и Реасила форте амино магний (вариант 6). Этот вариант обеспечил и самые высокие прибавки (см. табл. 1).

Препараты на основе гуминовых кислот оказали заметное влияние на качество урожая капусты (табл. 2). В вариантах с обработками в кочанах со-

Таблица 1

Влияние препаратов на основе гуминовых кислот на урожайность капусты белокочанной поздней гибрида Агрессор, т/га

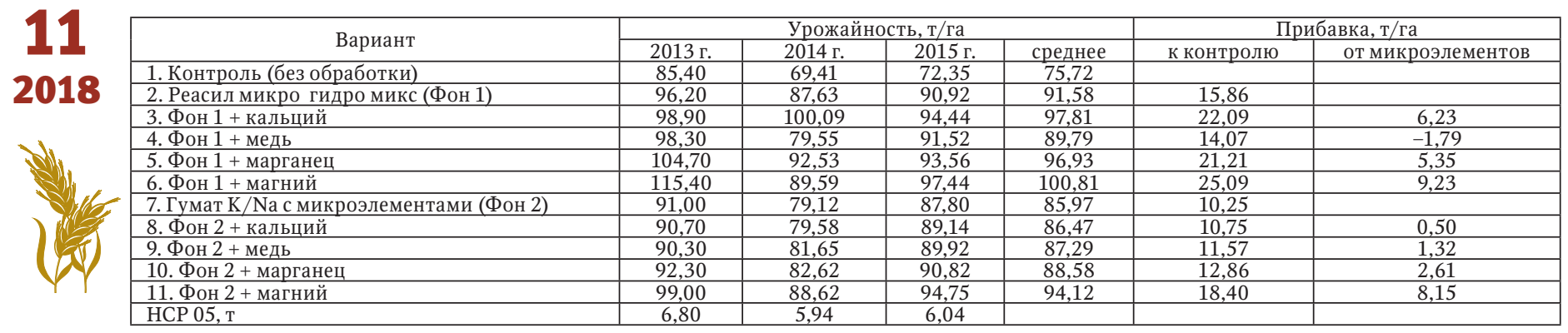


держалось больше азота (на 4-10 \% выше контроля), накапливалось больше фосфора (на 8 \%) и калия (на 3-7 \%). Это говорит о том, что изучаемые нами препараты способствовали лучшему развитию растений капусты. Кроме того, в продукции, полученной с удобренных делянок, содержалось больше сахаров (на 11-21 \% выше контроля) и витамина С (превышение над контролем на 6-10 \%). Что касается накопления в урожае сухого вещества (см. табл. 2), то во все годы исследований отмечали лишь незначительное его увеличение (на $2-3$ \%) после применения препаратов на основе гуминовых кислот. Количество нитратов в полученной продукции на всех вариантах опыта было практически одинаковым, ниже предельно допустимой концентрации. Следует также отметить, что на рассматриваемые показатели качества урожая изучаемые препараты оказали практически равное влияние.

Повышение урожайности капусты белокочанной, обусловленное применением препаратов на основе гуминовых кислот, привело к увеличению выноса питательных веществ из почвы (табл. 3). Больше всего капуста белокочанная поздняя поглощала из почвы калий. На втором месте по объему потребления - азот, а на третьем - фосфор. Максимальные значения выноса азота, фосфора и калия отмечали на варианте 6. Они были выше контроля в среднем за три года на $16-18 \%$.

На основании данных выноса элементов питания из почвы были рассчитаны показатели их потребления на единицу урожая (см. табл. 3). Установлено, что изучаемые нами препараты на основе гуминовых кислот способствовали более рациональному использованию растениями капусты питательных веществ на формирование урожая. Так, для получения 1 т продукции на варианте 6 потребовалось азота, фосфора и калия соответс- твенно на 5, 8 и 11 \% меньше, чем контрольным растениям.

Заключение. На орошаемых темно-каштановых террасовых почвах Саратовского Заволжья установлена высокая эффективность использования препаратов на основе гуминовых кислот при возделывании капусты белокочанной поздней. Максимальная урожайность этой культуры $(100,81$ т/га в среднем за три года) получена при совместном использовании Реасила микро гидро микс (1 л/га) и Реасила форте амино магний (две обработки по 1 л/га каждая).

Все изучаемые препараты производства НПО «Сила жизни» оказали положительное влияние на накопление в урожае элементов питания, сахаров и витамина С. При этом удобренные растения увеличивали вынос азота, фосфора и калия. Содержание нитратов в урожае на всех вариантах опыта (в том числе и на контроле) во все годы исследований было в 8-10 раз ниже предельно допустимых концентраций.

\section{СПИСОК ЛИТЕРАТУРЫ}

1. Доспехов Б.А. Методика полевого опыта. - 5-е изд., перераб. и доп. - М.: Агропромиздат, 1985. - 416 с.

2. Практикум по агрохимии / под ред. В.Г. Минеева. - 2-е изд., перераб. и доп. - М.: Изд-во Моск. ун-та, 2001. -689 c.

3. Пронько Н.А., Степанченко Д.А., Пронько В.В. Влияние гуминовых препаратов на продуктивность огурца на орошаемых каштановых почвах Саратовского Заволжья // Аграрный научный журнал. - 2018. - № 2. C. 31-35.

4. Пронько В.В., Степанченко Д.А., Пронько Н.А. Влияние гуминовых препаратов на продуктивность томата на орошаемых каштановых почвах Саратовского Заволжья // Аграрный научный журнал. - 2017. № 9. - C. 24-27.

5. Список пестицидов и агрохимикатов, разрешен-

Химический состав и качество урожая капусты белокочанной поздней гибрида Агрессор (в среднем за 2013-2015 гг.)

\begin{tabular}{|c|c|c|c|c|c|c|c|}
\hline \multirow[b]{2}{*}{ Вариант } & \multirow{2}{*}{$\begin{array}{c}\text { Сухое } \\
\text { вещество, \% }\end{array}$} & \multicolumn{3}{|c|}{ В \% на абс. сухое вещество } & \multirow{2}{*}{$\begin{array}{c}\mathrm{NO}_{3}, \text { мг/кг } \\
\text { сырой массы }\end{array}$} & \multirow{2}{*}{$\begin{array}{c}\text { Сумма } \\
\text { сахаров, \% }\end{array}$} & \multirow{2}{*}{$\begin{array}{c}\text { Витамин C, } \\
\text { мг } / \%\end{array}$} \\
\hline & & $\mathrm{N}$ & $\mathrm{P}_{2} \mathrm{O}$ & $\mathrm{K}_{2} \mathrm{O}$ & & & \\
\hline 1. Контроль (без обработки) & 9,8 & 1,98 & 0,53 & 2,58 & 57,2 & 2,8 & 23,7 \\
\hline 2. Реасил микро гидро микс (Фон 1$)$ & 9,9 & 2,05 & 0,54 & 2,63 & 58,2 & 3,1 & 25,2 \\
\hline 3. Фон $1+$ кальций & 9,8 & 2,09 & 0,56 & 2,65 & 57,9 & 3,2 & 25,6 \\
\hline 4. Фон $1+$ медь & 9,9 & 2,10 & 0,55 & 2,66 & 59,8 & 3,2 & 25,3 \\
\hline 5. Фон $1+$ марганец & 10,0 & 2,13 & 0,56 & 2,66 & 58,3 & 3,3 & 25,5 \\
\hline 6. Фон $1+$ магний & 9,9 & 2,15 & 0,56 & 2,71 & 57,9 & 3,3 & 25,9 \\
\hline 7. Гумат K/Na c микроэлементами (Фон 2) & 10,0 & 2,09 & 0,56 & 2,66 & 57,9 & 3,1 & 25,5 \\
\hline 8. Фон $2+$ кальций & 9,9 & 2,13 & 0,56 & 2,69 & 59,0 & 3,2 & 25,9 \\
\hline 9. Фон $2+$ медь & 9,9 & 2,17 & 0,56 & 2,71 & 59,1 & 3,3 & 25,7 \\
\hline 10. Фон $2+$ марганец & 9,9 & 2,14 & 0,56 & 2,73 & 57,9 & 3,4 & 25,8 \\
\hline 11. Фон $2+$ магний & 10,0 & 2,18 & 0,57 & 2,76 & 59,0 & 3,4 & 26,1 \\
\hline
\end{tabular}

Вынос элементов питания с урожаем капусты белокочанной поздней гибрида Агрессор (в среднем за 2013-2015 гг.)

\begin{tabular}{|c|c|c|c|c|c|c|}
\hline \multirow{2}{*}{ Вариант } & \multicolumn{3}{|c|}{ Вынос элементов питания, кг/га } & \multicolumn{3}{|c|}{ Потребление элементов питания на 1 т продукции, кг } \\
\hline & $\mathrm{N}$ & $\mathrm{P}_{2} \mathrm{O}_{5}$ & $\mathrm{~K}_{2} \mathrm{O}$ & $\mathrm{N}$ & $\mathrm{P}_{2} \mathrm{O}_{5}$ & $\mathrm{~K}_{2} \mathrm{O}$ \\
\hline 1. Контроль (без обработки) & 239 & 81 & 342 & 3,17 & 1,08 & 4,52 \\
\hline 2. Реасил микро гидро микс (Фон 1) & 283 & 94 & 382 & 3,10 & 1,03 & 4,17 \\
\hline 3. Фон $1+$ кальций & 296 & 100 & 392 & 3,03 & 1,02 & 4,00 \\
\hline 4. Фон $1+$ медь & 269 & 91 & 361 & 3,00 & 1,02 & 4,03 \\
\hline 5. Фон $1+$ марганец & 292 & 97 & 391 & 3,02 & 1,01 & 4,03 \\
\hline 6. Фон $1+$ магний & 301 & 102 & 405 & 3,00 & 1,02 & 4,01 \\
\hline 7. Гумат K/Na с микроэлементами (Фон 2) & 265 & 88 & 354 & 3,08 & 1,02 & 4,12 \\
\hline 8. Фон $2+$ кальций & 261 & 87 & 339 & 3,02 & 1,00 & 3,93 \\
\hline 9. Фон $2+$ медь & 263 & 85 & 347 & 3,02 & 1,00 & 3,98 \\
\hline 10. Фон $2+$ марганец & 267 & 89 & 351 & 3,02 & 1,00 & 3,97 \\
\hline 11. Фон $2+$ магний & 278 & 93 & 383 & 2,96 & 0,99 & 4,08 \\
\hline
\end{tabular}


ных к применению на территории Российской Федерации. Справочное издание. - М., 2018. - 816 с.

6. Шеуджен А.Х., Онищенко Л.М., Прокопенко В.В. Удобрения, почвенные грунты и регуляторы роста растений. - Майкоп, 2005. - 404 с.

Пронько Нина Анатольевна, $\partial-p$ c.- $x$. наук, проф. кафедры «Инженерные изыскания, природообустройство и водопользование», Саратовский государственный аграрный университет имени Н.И. Вавилова. Россия.

Шушков Юрий Сергеевич, аспирант кафедры «Инженерные изыскания, природообустройство и водопользова- ние», Саратовский государственный аграрный университет имени Н.И. Вавилова. Россия.

410012, г. Саратов, Театральная пл., 1.

Тел.: (8452) 23-27-83.

Пронько Виктор Васильевич, $\partial-p c .-x$. наук, проф., зав. отделом науки и развития, НПО «Сила жизни». Россия. 410005, г. Саратов, ул. Б. Садовая, 239.

Тел.: (8452) 44-40-40.

Ключевые слова: препараты на основе гуминовых кислот; капуста белокочанная позднеспелая; орошение; темнокаштановые почвы; Саратовское Заволжье.

\title{
THE INFLUENCE OF HUMIC ACIDS BASED PRODUCTS ON THE PRODUCTIVITY OF WHITE CABBAGE WITH IRRIGATION
}

Pronko Nina Anatolievna, Doctor of Agricultural Sciences, Professor of the chair "Engineering Surveying, Environmental Engineering and Water Consumption", Saratov State Agrarian University named after N.I. Vavilov. Russia.

Shushkov Yuri Sergeevich, Post-graduate Student of the chair "Engineering Surveying, Environmental Engineering and Water Consumption", Saratov State Agrarian University named after N.I. Vavilov. Russia.

Pronko Viktor Vasilievich, Doctor of Agricultural Sciences, Professor, Head of the Department of Science and Development, LIFE FORCE LLC. Russia.

Keywords: humic acids based products; late-ripening white cabbage; irrigation; dark chestnut soils; The Volga region.

The influence of humic acids based products on the productivity of late-ripening white cabbage hybrid "Aggressor" has been studied. It is established that spraying of plants with the solution of Reasil Micro Hydro Mix increased the yield of cabbage heads by $15.8 \mathrm{t} / \mathrm{ha}$ (21\% higher than control). Treatment with the solution of Humate $\mathrm{K}-\mathrm{Na}$ with microelements increased the productivity of cabbage by $10.25 \mathrm{t} / \mathrm{ha}$ (14\% higher than control). Maximum yield of white cabbage within the ex-periment (100.81 t/ha) was obtained with double application of Reasil Forte Amino Magnesium on the background of Reasil micro Hydro Mix. All studied products based on humic acids positively influenced on accumulation of dry matter, vitamin $C$, the amount of sugars and the content of nutrients. At the same time, they also contributed to an increased removal of nitrogen, phosphorus and potassium from the soil. The products did not affect the content of nitrate nitrogen in the products.

\section{ВЛИЯНИЕ ПОГОДНЫХ УСЛОВИЙ НА РАЗВИТИЕ ОИДИУМА ВИНОГРАДА В СТЕПНОЙ ЗОНЕ НИЖНЕГО ПОВОЛЖЬЯ}

\author{
РЯЗАНЦЕВ Никита Валерьевич, Саратовский государственный аграрный университет
}

имени Н.И. Вавилова

\begin{abstract}
РЯБУШКИН Юрий Борисович, Саратовский государственный аграрный университет имени Н.И. Вавилова
\end{abstract}

\author{
ЕСЬКОВ Иван Дмитриевич, Саратовский государственный аграрный университет \\ имени Н.И. Вавилова
}

\begin{abstract}
МОРОЗОВА Светлана Владимировна, Саратовский государственный научный исследовательский университет имени Н.Г. Чернышевского
\end{abstract}

Изучены особенности развития оидиуа в условиях степной зоны Нижнего Поволжъя на 33 сортах винограда с учетом погодных условий данного региона. Показано, что из семи лет наблюдений два года характеризовалисъ эпифитотиями оидиума, два года развитие болезни происходило в средней степени, три года причиняла минимальный ущерб. Выявлены наиболее благоприятные погодные условия для развития болезни. Макроскопическое изучение распространения оидиума показало, что сорта винограда обладают различной устойчивостью к возбудителю этой болезни. Выделены следующие группы сортов: неустойчивые - Жемчуг Саба, Мадлен Анжевин, Шасла белая; среднеустойчивые - Алешенькин, Болгария, Виктория, Украинка, Цветочный; толерантные - Бианка; Кишмиш Мираж, Левокумский устойчивый, Мускат летний; высокоустойчивые - Августин, Аркадия, Восторг, Восторг идеалъный, Восторг красный, Восторг черный, ГФ 14-75, Кантемировский, Кобзаръ, Коринка русская, Люси белая, Памяти Негруля, Плевен европейский, Смуглянка молдавская, Талисман, Эзоп; оченъ высокоустойчивые - Бако черный, Кишмиш Венгерский, Лидия, Нектарный, Северный плечистик. Для промышленного выращивания винограда в условиях степной зоны Нижнего Поволжъя рекомендуются сорта, характеризующиеся повышенной устойчивостью к оидиум.

Введение. Почвенно-климатические условия степной зоны Нижнего Поволжья в целом благоприятны для развития виноградарства $[9,10]$. Однако погодные условия периода вегетации здесь отличаются от условий в регионах традиционного выращивания винограда на юге [1]. Это обуслов- ливает некоторые особенности развития болезней данной культуры. Большой вред винограду наносит оидиум - настоящая мучнистая роса (возбудитель сумчатый гриб Uncinula necator [Schwein.] Burr.) [2, $4,5]$. Развитие оидиума в рассматриваемом регионе характеризуется некоторыми особенностями. 